\title{
Analisis Produktivitas Menggunakan Metode Objective Matrix (OMAX) (Studi Kasus: Departemen Produksi PT Elang Jagad)
}

\author{
Ajeng Risky Mukti' ${ }^{1}$, Qurotul A'yun ${ }^{2}$, Suparto $^{3}$ \\ 1,2,3 Jurusan Teknik Industri, Fakultas Teknologi Industri, Institut Teknologi Adhi Tama Surabaya \\ Email: ${ }^{1}$ ajengrsky@gmail.com, ${ }^{2}$ qurotulayun99@gmail.com, ${ }^{3}$ suparto@itats.ac.id
}

\begin{abstract}
PT Elang Jagad is a manufacturing industry engaged in metal processing. One of the products produced is seal spacers for bicycles. Along with the times. PT Eagle Jagad always tries to maintain and increase its existence in the industrial world. One of the factors that must be considered is productivity. Productivity assessment can be seen from the comparison of the company's input and output values. In this study, the input data used are data on the amount of electricity consumption, the number of workers, and the number of hours worked. Meanwhile, the output data used is the product finish good data in the form of seal spacers. Based on the calculations that have been done, it can be seen that the index of change to the best standard productivity occurred in August 2020, amounting to 114.47. Meanwhile, the worst productivity occurred on June 1, 2020, amounting to -88.41 . The index of change to the productivity of the previous period can be seen that the best productivity occurred in July 2020, amounting to 887.49. As for the worst productivity occurred in June 2020 , which was -90 . The lowest attribute ratio can be determined by looking at the table of achieving the lowest score, so it is known that ratio 2 (labor) has poor productivity because it has the lowest score compared to ratio 1 (electricity usage) and a ratio of 3 (hours of work).
\end{abstract}

Keywords: Fishbone, Index value, Productivity, OMAX, Overall productivity

\begin{abstract}
Abstrak
PT Elang Jagad merupakan salah satu industri manufaktur yang bergerak di pengolahan logam. Salah satu produk yang diproduksi ialah seal spacer untuk sepeda. Seiring dengan perkembangan jaman. PT Elang Jagad selalu berusaha mempertahankan dan meningkatnya eksistensinya di dunia industry. Salah satu faktor yang harus diperhatikan ialah produktivitas. Penilaian produktivitas dapat dilihat dari perbandingan nilai input dan output perusahaan. Pada penelitian ini, data input yang digunakan ialah data jumlah pemakaian listrik, jumlah tenaga kerja, dan jumlah jam kerja. Sedangkan untuk data output yang digunakan ialah data finish good produk yang berupa seal spacer. Berdasarkan perhitungan yang telah dilakukan dapat diketahui bahwa indeks perubahan terhadap produktivitas standart terbaik terjadi pada Agustus 2020 yaitu sebesar 114,47. Sedangkan untuk produktivitas terburuk terjadi padsa 1 Juni 2020 sebesar $-88,41$. Indeks perubahan terhadap produktivitas periode sebelumnya dapat diketahui bahwa produktivitas terbaik terjadi pada Juli 2020 yaitu sebesar 887,49. Sedangkan untuk produktivitas terburuk terjadi pada Juni 2020 yaitu sebesar -90 . Atribut rasio yang paling rendah dapat ditentukan dengan melihat tabel pencapaian skor terendah, sehingga diketahui bahwa rasio 2 (tenaga kerja) memiliki produktivitas yang kurang baik karena memiliki skor terendah dibandingkan dengan rasio 1 (penggunaan listrik) dan rasio 3 (jam kerja).
\end{abstract}

Kata Kunci: Fishbone, Nilai indeks, Produktivitas, OMAX, Overall produktivitas

\section{Pendahuluan}

Perkembangan sebuah dunia industry yang begitu pesat pada saat sekarang ini menuntut sebuah perusahaan memiliki kemampuan dalam bersaing. Daya saing sebuah perusahaan dapat diukur melalui tingkat produktivitas dari proses bisnis yang telah dijalankan oleh perusahaan. Apakah terjadipeningkatan atau penurunun [1]. PT Elang Jagad merupakan sebuah perusahaan yang bergerak di bidang manufaktur logam yang telah berdiri sejak tahun 2001. 
Kata produktivitas akan selalu dihubungkan dengan kuantitas pada masukan atau input dan keluaran atau output yang digunakan dalam sebuah proses produksi baik jasa ataupun barang. Produktivitas berfokus pada seberapa efisien dan efektif barang atau jasa yang telah diproduksi tersebut dan biaya yang akan ditimbulkan akibat sebuah proses produksi.[2] Menurut Zanuar dalam Fani.[3] pengukuran produktivitas dapat dilakukan dengan cara memperhatikan kondisi pada perusahaan, sehingga ukuran yang di dapat mampu memberikan gambaran yang jelas dari tingkat produktivitas perusahaan. Penggunaan terhadap sumber daya bahan baku, energy, tenaga kerja dan mesin yang kurang efisien dan efektif selama kegiatan produksi mendorong perusahan untuk meningkatkan produkvitasnya. Oleh sebab itu, perusahaan perlu melakukan pengukuran terhadap produktivitasnya untuk mengetahui faktor apa saja yang mempengaruhi produktivitas.

Produktivitas ditemukan karena adanya sebuah transformasi yang berlangsung. Proses transformasi adalah sebuah rangkaian aktivitas yang dilakukan untuk mengubah / mengolah sejumlah masukan / input menjadi sejumlah keluaran / output yang memiliki nilai tambah. Pengolahan yang bertambah dalam pengertian nilai guna atau nilai ekonominya.[4] Menurut Haizer pada Kusuma[5], produktivitas adalah perbandingan keluaran / output (jasa / barang) dibagi dengan masukan / input (sumber daya, seperti tenaga kerja, modal). Pekerjaan seorang manajer operasi ialah untuk meningkatkan sebuah rasio dari hasil atau keluaran / output atas masukan / input. Peningkatan produktivitas mengartikan peningkatan efisiensi. Sedangkan menurut Dewan Produktivitas Nasional dalam Sumath pada Fithri [6] menyatakan bahwa produktivitas ialah perbandingan dari hasil yang telah dicapai dengan keseluruhan sumber daya yang telah digunakan. Selanjutnya, Paul Mail juga menyatakan produktivitas berbeda dengan produksi, tetapi produksi, performansi kualitas, hasil-hasil ialah komponen dari usaha produktivitas.

Pada penelitian sebelumnya telah dilakukan pengukuran produktivitas dengan metode OMAX namun hanya saja di bidang yang berbeda. Pada tahun 2019 terdapat beberapa penelitian yang meneliti tentang analisis produktivitas di berbagai bidang manufaktur. Terdapat Evita yang melakukan penelitian analisis penelitian produktivitas pada pabrik Roti di Bali. Terdapat Putu melakukan analisis produktivitas pada pabrik obat di Bali. Di tahun yang sama, Gamindra melakukan penelitian mengenai penerapan OMAX untuk menganalisa produktivitas di sebuah pabrik obat. Dan pada tahun 2017, Hana melakukan penelitian tentang implementasi OMAX untuk pengukuran produktivitas. Dengan mempertimbangan hal tersebut, di makalah ini akan membahas tentang analisis produktivitas dengan metode OMAX di PT Elang Jagad, Sidoarjo.

\section{Metode}

Penelitian ini dilakukan di PT Elang Jagad yang terletak di Jl. Kolonel Sugiono No. 53, Ngigas, Sidoarjo, Jawa Timur. Waktu pelaksanaan dalam pengumpulan data dilakukan dari 5 Oktober 2020 sampai dengan 5 November 2020.

Tahapan penelitian terdiri dari penentuan rasio produktivitas berdasarkan (1) studi literatur dan observasi, (2) Pengumpulan data dengan wawancara, observasi dan studi pustaka. Data yang dikumpulkan ialah data output seal spacer, jumlah tenaga kerja, pemakaian energy, dan jumlah dengan menggunakan metode Objective Matrix dan Fishbone Diagram, (4) Analisa hasil dilakukan dengan menganalisa hasil pengukuran produktivitas dan melakukan perbaikan dengan fish diagram, (5) Kesimpulan dan saran hasil penelitian.

\section{Hasil dan Pembahasan}

\section{Objective Matrix}

Menurut Ramadhani[7] Objective Matrix ialah suatu sistem dari pengukuran produktivitas parsial yang telah dikembangkan dengan tujuan memantau produktivitas setiap bagian perusahaan dengan kriteria produktivitas yang sesuai dengan keberadaan bagian tersebut. objective matrix memiliki ciri yang unik ialah dengan menggabungkannya kriteria performansi kelompok kerja di dalam suatu matrix. [8]

Untuk perhitungan Objective Matrix, dilakukan dengan Langkah-langkah sebagai berikut: (1) Penentuan besar bobot setiap kriteria berdasarkan kepentingan lalu di konversikan, (2) Perhitungan 
rasio setiap kriteria, output, dan setiap input yang ada, (3) Penyusunan tabel omax, setelah rasio setiap kriteria diketahui dapat dilanjutkan dengan menyusin tabel omax dengan cara interpolasi dengan rumus, dan (4) Hasil pencapaian skor setiap kriteria, setelah dilakukan penyusunan tabel omax, maka skor setiap rasio akan diketahui seperti Tabel 1. Rumus yang digunakan untuk interpolasi sebagai berikut: [9]

Kenaikan level 1 dan $2=\frac{\text { level } 3-\text { level } 0}{3-0}$

Kenaikan level $4-9=\frac{\text { level } 10-\text { level } 3}{10-3}$

Tabel 1. Pencapaian skor OMAX

\begin{tabular}{ccccc}
\hline NO & Periode & Kriteria 1 & Kriteria 2 & Kriteria 3 \\
\hline 1 & Mei & 10 & 0 & 0 \\
\hline 2 & Juni & 1 & 0 & 0 \\
\hline 3 & Juli & 9 & 0 & 1 \\
\hline 4 & Agustus & 8 & 7 & 4 \\
\hline 5 & September & 0 & 4 & 3 \\
\hline 6 & Oktober & 1 & 10 & 10 \\
\hline & Total & 29 & 21 & 18 \\
\hline
\end{tabular}

Dari Tabel 1 pencapaian skor menunjukkan bahwa tingkat rasio produktivitas terbaik terdapat pada periode Oktober, Sedangkan untuk tingkat rasio terburuk terjadi pada periode Juni. Untuk rasio yang kurang memberikan kontribusi terhadap indeks produktivitas adalah kriteria 3 yaitu jam kerja karena mempunyai skor yang kecil. Banyak hal yang mempengaruhi.

Didalam mencapai produktivitas yang tinggi pada proses produksi di PT Bagian Didalam mencapai produktivitas yang tinggi pada proses produksi di PT Elang Jagad, jam kerja harus optimal dan proses juga harus didukung oleh faktor seperti teknologi yang baru, agar dengan jam kerja yang memenuhi faktor pendukung tersebut dalam produktivitas kerja, dapat menghasilkan jam kerja yang berkualitas, efektif, dan efisien.

\section{Evaluasi Tingkat Produktivitas}

Tabel 2. Evaluasi Tingkat Produktivitas

\begin{tabular}{cccc}
\hline Periode & $\begin{array}{c}\text { Overal } \\
\text { Produktivity (OP) }\end{array}$ & $\begin{array}{c}\text { Nilai Indeks Perubahan } \\
\text { Terhadap Produktivitas } \\
\text { Periode Standart }\end{array}$ & $\begin{array}{c}\text { Nilai Indeks Perubahan } \\
\text { Terhadap Produktivitas Periode } \\
\text { Sebelumnya }\end{array}$ \\
\hline Mei & 347,80 & 15,93 & 15,93 \\
\hline Juni & 34,78 & $-88,41$ & $-90,00$ \\
\hline Juli & 343,45 & 14,48 & 887,49 \\
\hline Agustus & 643,42 & 114,47 & 87,34 \\
\hline September & 230,41 & $-23,20$ & $-64,19$ \\
\hline Oktober & 686,88 & 128,96 & 198,11 \\
\hline
\end{tabular}

Dari tabel 2 evaluasi tingkat produktivitas yang di dapatkan dari perhitungan OMAX dapat diketahui bahwa produktvitas terbaik terjadi pada bulan Oktober 2020 yaitu sebesar 686,88. Sedangkan untuk produktivitas terburuk terjadi pada bulan September 2020 sebesar 230,41. Dari nilai indeks perubahan terhadap produktivitas standart dapat diketahui bahwa produktivitas terbaik terjadi pada bulan Oktober 2020 sebesar 128,96. Sedangkan untuk produktivitas terburuk terjadi pada bulan Juni 2020 yaitu sebesar $-88,41$. 
Dari nilai indeks perubahan terhadap produktivitas periode sebelumnya dapat diketahui bahwa produktivitas terbaik pada bulan Juli 2020 yaitu sebesar 887,49. Sedangkan untuk produktivitas terburuk terjadi pada bulan Juni yaitu - 90. Dari tabel 2 dapat diketahui bahwa perubahan indeks produktivitas dari Overall Productivity, nilai indeks perubahan terhadap produktivitas periode standart, dan nilai indeks perubahan terhadap produktivitas periode sebelumnya dengan nilai yang sangat fluktuatif di pengaruhi oleh fluktuatifnya output, tenaga kerja, dan jam kerja yang dipengaruhi oleh tanggal merah dan jumlah energy yang dipakai.

\section{Fishbone Diagram}

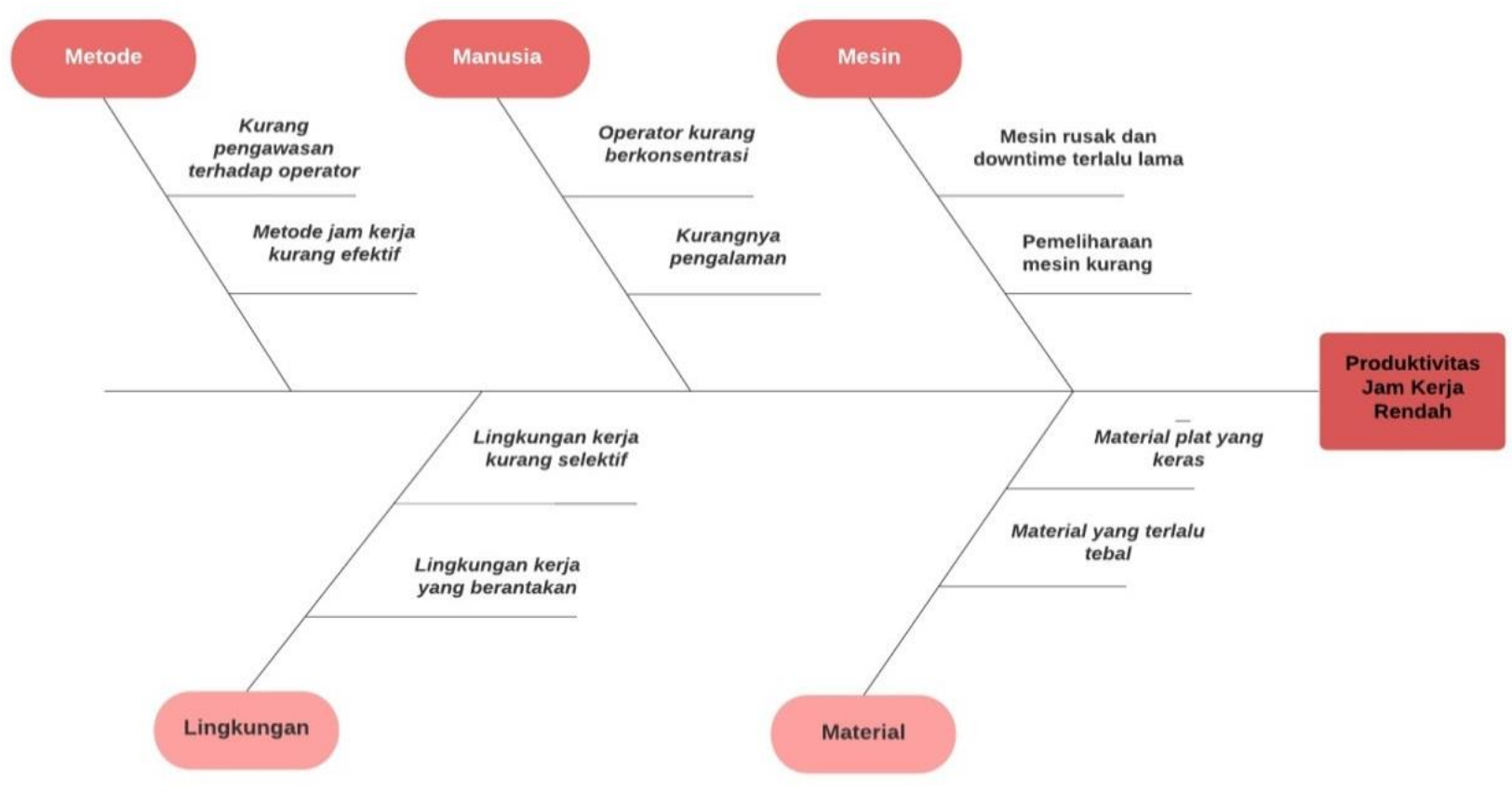

Gambar 1. Fishbone Diagram

Dari gambar 2 yang menggambarkan sebuah fishbone terdapat factor-faktor yang mempengaruhi penurunan dari produktivitas, maka dilakukan pada jam kerja seperti:

Tabel 3. Usulan Perbaikan

\begin{tabular}{|c|c|c|c|}
\hline Faktor & Penyebab & Standart & Usulan Perbaikan \\
\hline \multirow[t]{2}{*}{ Manusia } & $\begin{array}{l}\text { Operator kurang } \\
\text { berkonsentrasi }\end{array}$ & $\begin{array}{l}\text { Operator bekerja sesuai } \\
\text { prosedur yang berlaku }\end{array}$ & $\begin{array}{c}\text { Menyediakan tempat kerja yang } \\
\text { nyaman }\end{array}$ \\
\hline & $\begin{array}{c}\text { Tenaga kerja kurang } \\
\text { berpengalaman }\end{array}$ & $\begin{array}{c}\text { Tenaga kerja harus memiliki } \\
\text { standar } \\
\text { pengalaman yang baik }\end{array}$ & $\begin{array}{c}\text { Mengadakan pelatihan untuk } \\
\text { tenaga kerja }\end{array}$ \\
\hline \multirow[t]{2}{*}{ Mesin } & $\begin{array}{c}\text { Mesin rusak dan waktu } \\
\text { downtime lama }\end{array}$ & $\begin{array}{c}\text { Pengecekan mesin sebelum } \\
\text { digunakan }\end{array}$ & $\begin{array}{c}\text { Pengalihan tanggung jawab dari } \\
\text { operator ke } \\
\text { Pengawas }\end{array}$ \\
\hline & $\begin{array}{l}\text { Pemeliharaan mesin } \\
\text { kurang }\end{array}$ & Perbaikan part secara berkala & $\begin{array}{l}\text { Pergantiann part setiap 2-3 hari } \\
\text { sekali }\end{array}$ \\
\hline
\end{tabular}




\begin{tabular}{|c|c|c|c|}
\hline Faktor & Penyebab & Standart & Usulan Perbaikan \\
\hline \multirow[t]{2}{*}{ Metode } & $\begin{array}{l}\text { Kurang pengawasan } \\
\text { terhadap operator }\end{array}$ & $\begin{array}{c}\text { Operator perlu mendapat } \\
\text { pengawasan }\end{array}$ & $\begin{array}{c}\text { Pengawasan yang sesuai dengan } \\
\text { standart perusahaan }\end{array}$ \\
\hline & $\begin{array}{l}\text { Metode jam } \\
\text { Kerja }\end{array}$ & $\begin{array}{l}\text { Jam kerja harus memiliki } \\
\text { standar prosedur dengan } \\
\text { mempertimbangkan output } \\
\text { produksi }\end{array}$ & $\begin{array}{l}\text { Perbaikan pada jam kerja tenaga } \\
\text { kerja produksi }\end{array}$ \\
\hline \multirow[t]{2}{*}{ Material } & Metrial plat yang keras & $\begin{array}{c}\text { Material yang tidak keras } \\
\text { dengan ketebalan sama }\end{array}$ & $\begin{array}{c}\text { Pemilihan supplier material } \\
\text { yang lebih selektif }\end{array}$ \\
\hline & Material yang terlalu tebal & $\begin{array}{l}\text { Material yang tidak tebal sesuai } \\
\text { kemampuan mesin }\end{array}$ & $\begin{array}{l}\text { Pemilihan bahan yang lebih } \\
\text { selektif dari supplier }\end{array}$ \\
\hline \multirow[t]{2}{*}{ Lingkungan } & $\begin{array}{c}\text { Lingkungan kerja yang } \\
\text { berantakan }\end{array}$ & $\begin{array}{c}\text { Lingkungan kerja yang rapi dan } \\
\text { sesuai } \\
\text { dengan standart K3 }\end{array}$ & \multirow{2}{*}{$\begin{array}{l}\text { Menstandarisasi lingkungan } \\
\text { kerja yang sesuai dengan } \\
\text { standar K3 Penambahan } \\
\text { penerangan dan ventilator pada } \\
\text { ruang produksi }\end{array}$} \\
\hline & $\begin{array}{l}\text { Lingkungan kerja kurang } \\
\text { selektif }\end{array}$ & $\begin{array}{l}\text { Lingkungan kerja yang dengan } \\
\text { maksimum penerangan dan } \\
\text { ventilator }\end{array}$ & \\
\hline
\end{tabular}

\section{Kesimpulan}

Indeks produktivitas dapat dihitung dengan menghitung nilai overall productivity terlebih dahulu, sehingga didapat nilai indeks perubahan terhadap produktivitas standart dan indeks perubahan terhadap produktivitas periode sebelumnya. Diketahui bahwa indeks perubahan terhadap produktivitas standart terbaik terjadi pada Agustus 2020 yaitu sebesar 114,47. Sedangkan untuk produktivitas terburuk terjadi padsa 1 Juni 2020 sebesar $-88,41$. Indeks perubahan terhadap produktivitas periode sebelumnya dapat diketahui bahwa produktivitas terbaik terjadi pada Juli 2020 yaitu sebesar 887,49. Sedangkan untuk produktivitas terburuk terjadi pada Juni 2020 yaitu sebesar -90. Atribut rasio yang paling rendah dapat ditentukan dengan melihat tabel pencapaian skor terendah, sehingga diketahui bahwa rasio 2 (tenaga kerja) memiliki produktivitas yang kurang baik karena memiliki skor terendah dibandingkan dengan rasio 1 (penggunaan listrik) dan rasio 3 (jam kerja).

\section{Referensi}

[1]Ｏktaviani.J, “済無No Title No Title,” Sereal Untuk, vol. 51, no. 1, p. 51, 2018.

[2] D. M. R. Ristanti and R. Prabowo, "Analisis produktivitas dengan pendekatan metode apc di perusahaan jasa uji tak merusak/ndt," in Conference on Innovation and Application of Science and Technology (CIASTECH), 2018, vol. 1, no. 1, pp. 469-477.

[3] F. Tania and M. Ulkhaq, "Pengukuran dan Analisis Produktivitas di PT. Tiga Manunggal Synthetic Industries dengan Menggunakan Metode Objective Matrix (OMAX)," Industrial Engineering Online Journal, vol. 5, no. 4, 2016.

[4] F. P. Suprobo, N. Hariastuti, C. Mardiana, R. Prihatin, and S. Suparjo, "Pengukuran produktivitas kinerja UKM sandang-kulit berdasarkan aspek produksi dan pemasaran," Jurnal Eco-Teknologi UWIKA (eJETU), vol. 1, no. 1, pp. 07-11, 2013.

[5] T. I. M. M. B. KIDUL and K. WARDANI, "PENGUKURAN PRODUKTIVITAS MENGGUNAKAN METODE APC (AMERICAN PRODUKCTIVITY CENTER) PADA SENTRA UMKM.".

[6] P. Fithri and R. Y. Sari, "Analisis Pengukuran Produktivitas Perusahaan Alsintan CV. Cherry Sarana Agro," Jurnal Optimasi Sistem Industri, vol. 14, no. 1, pp. 138-155, 2016. 
[7] S. N. Ramadhani, A. C. Prihandoko, and N. O. Adiwijaya, "Sistem Informasi Pengukuran Produktivitas Hotel di Kabupaten Jember Menggunakan Metode OMAX (Objective Matrix) dan AHP (Analytical Hierarchy Process)(Studi Kasus Hotel Istana)," BERKALA SAINSTEK, vol. 6, no. 1, pp. 10-16, 2018.

[8] D. Avianda, Y. Yuniati, and Y. Yuniar, "Strategi Peningkatan Produktivitas di Lantai Produksi Menggunakan Metode Objective Matrix," Reka Integra, vol. 1, no. 4, 2013.

[9] R. Setiowati, "Analisis pengukuran produktivitas departemen produksi dengan metode Objective Matrix (OMAX) pada CV. Jaya Mandiri," vol, vol. 10, pp. 199-209, 2017. 